\title{
PENGARUH PENGALAMAN KERJA TERHADAP KINERJA KARYAWAN PADA TOKO EMAS SEMAR NGANJUK
}

\author{
Bagus Aries Riyadi \\ Mahasiswa Prodi Pendidikan Ekonomi IKIP PGRI Madiun
}

\begin{abstract}
Abstrak: Penelitian ini bertujuan untuk mengetahui apakah ada pengaruh pada kinerja pengalaman kerja karyawan di toko emas Semar Nganjuk. Sampel dalam penelitian ini menggunakan sampel berguna yang semua karyawan di toko emas Semar Nganjuk, terdiri dari 40 orang. Pengumpulan data dalam penelitian ini menggunakan kuesioner. Berdasarkan hasil perhitungan, dapat lebih dikenal besarnya korelasi (r) adalah 0,345 yang merupakan korelasi positif, yaitu jika pengalaman kerja (X) meningkat secara proporsional dengan kinerja karyawan $(\mathrm{Y})$ juga meningkat. Dan dengan demikian sebaliknya jika pengalaman kerja $(\mathrm{X})$ menurun secara proporsional dengan kinerja karyawan $(\mathrm{Y})$ juga akan menurun. Hal ini membuat jelas bahwa untuk meningkatkan kinerja karyawan di toko emas Semar Nganjuk harus bekerja untuk meningkatkan pengalaman kerja setiap karyawan. Hal ini menunjukkan bahwa kinerja aktual karyawan yang baik tidak harus bergantung pada pengalaman kerja. Analisis statistik lain dari hasil adalah untuk menghitung nilai F. Hasil hitung $\mathrm{F}$ adalah 1897 dan tabel $\mathrm{F}=2,023$, yang berarti bahwa $\mathrm{F}_{\text {hitung }}<\mathrm{F}_{\text {tabel }}=$ Terima $\mathrm{H}_{0}$. Dari hasil ini yang membuktikan bahwa $\mathrm{H}_{0}$ diterima, dinyatakan bahwa tidak ada korelasi antara kedua variabel, pengalaman kerja $(\mathrm{X})$ dan kinerja karyawan $(\mathrm{Y})$. Ini menyiratkan bahwa sebenarnya kinerja karyawan tidak hanya tergantung atau dipengaruhi oleh pengalaman kerja karyawan, tetapi ada faktor lain yang berpengaruh terhadap kinerja karyawan sebagai faktor lain yang berpengaruh pada faktor-faktor kinerja pegawai seperti pendidikan, usia, dan kesehatan karyawan bahwa kita tidak belajar dalam penelitian ini.
\end{abstract}

Kata kunci: Kinerja, Pengalaman kerja

\section{PENDAHULUAN}

Dalam melakukan aktifitasnya setiap perusahaan selalu berorientasi pada pencapaian tujuan yang telah ditetapkan oleh perusahaan tersebut, sekaligus tercapai efisiensi dan produktivitas yang tinggi. Semakin pesatnya perkembangan ilmu dan teknologi serta datangnya era pasar bebas sekarang ini, dunia bisnis semakin dipenuhi dengan persaingan yang cukup ketat. Salah satu faktor yang tidak boleh dilupakan oleh perusahaan adalah sumber daya manusia. Faktor yang paling penting dan menentukan terhadap keberhasilan pencapaian tujuan adalah sumber daya manusia, yang meliputi pendidikan, kejujuran, loyalitas, dan kinerja.

Pengalaman kerja, yaitu pengalaman seseorang tenaga kerja untuk melakukan pekerjaan tertentu, pengalaman pekerjaan ini dinyatakan dalam pekerjaan yang harus dilakukan dan lamanya melakukan pekerjaan itu.

Karyawan adalah makhluk sosial yang menjadi kekayaan utama bagi setiap perusahaan. Mereka ini menjadi perencanaan, pelaksana dan pengendali yang selalu berperan aktif dan mewujudkan tujuan perusahaan. Karyawan ini menjadi pelaksana yang menunjang tercapainya tujuan, mempunyai tujuan, mempunyai pikiran, perasaan dan keinginan yang dapat mempengaruhi pikiran sikap-sikapnya terhadap pekerjaannya.

Keberhasilan pengelolaan sangat ditentukan oleh kegiatan pendayagunaan 
sumber daya manusia. Dari pendapat tersebut diketahui bahwa manusia merupakan sumber daya yang sangat potensial dalam menentukan keberhasilan perusahaan, oleh karena itu harus diperhatikan agar kelancaran perusahaan tetap terpelihara dan semakin meningkat. Kualitas sumber daya manusia bisa dilihat dari hasil kerjanya, dalam kerangka profesionalisme kinerja yang baik adalah sebagaimana seorang pegawai mampu memperlihatkan perilaku kerja yang mengarah pada tercapainya maksud dan tujuan perusahaan, misalnya bagaimana caranya mengelola sumber daya manusia agar mengarah pada hasil kerja yang baik, karena manusia bisa menjadi pusat masalah bagi perusahaan ketika potensi mereka tidak dikembangkan secara optimal, sebaliknya manusia bisa menjadi pusat keberhasilan bagi perusahaan manakala potensi mereka dikembangkan secara baik dan optimal.

Secara internal, dalam pengelolaan dan pembenahan manajemen perusahaan, sumber daya manusia menempati posisi yang strategis. Walaupun didukung modal yang besar serta teknologi yang handal tanpa didukung oleh sumber daya manusia yang mampu untuk menjalankannya maka tujuan perusahaan tidak akan tercapai. Tujuan mendirikan perusahaan adalah untuk memperoleh keuntungan yang optimal sesuai dengan perencanaan yang telah dibuat.

Dalam perkembangan perusahaan diharapkan mengalami kemajuan, harapan yang cerah dikemudian hari merupakan salah satu dasar untuk mengambil tindakantindakan yang dianggap diperlukan pada saat sekarang. Namun dalam hal ini perusahaan memelihara dan mengembangkan perusahaan yang sudah didirikan merupakan suatu penerapan yang jauh lebih berat karena akan menyangkut berbagai macam masalah yang lebih banyak dan silih berganti. Jadi meski pun suatu perusahaan memiliki peralatan yang modern dengan teknologi tinggi tetap manusia sebagai motor penggerak, dalam hal ini adalah para tenaga kerja atau karyawan, tanpa sumber daya manusia dan pengalaman kerja pada karyawan perusahaan tidak akan berfungsi sebagaimana mestinya.

Di sinilah tujuan memahami dan mempelajari manajemen sumber daya manusia sebagai suatu pengetahuan yang diperlukan untuk memiliki kemampuan menganalisa dalam menghadapi masalah-masalah manajemen khususnya di bidang organisasi.

Adanya upaya menggunakan pengalaman kerja maka akan menghasilkan sumber daya manusia yang berkualitas, dalam hal ini adalah kinerja dari karyawan yang bersangkutan dan mampu memberikan kontribusi yang terbaik dalam pencapaian tujuan perusahaan. Tujuan perusahaan dalam bidang sumber daya manusia adalah agar sumber daya manusia atau tenaga kerja yang dimilikinya benar-benar dapat bekerja sesuai dengan apa yang diinginkan oleh perusahaan. Artinya kinerja organisasi atau perusahaan sangat dipengaruhi dan bahkan tergantung pada kualitas dan kemampuan sumber daya manusia atau kinerja karyawan yang dimilikinya. Oleh karena itu peranan sumber daya manusia dalam perusahaan sangatlah penting karena sebagai penggerak utama seluruh aktivitas perusahaan.

Berhasil tidaknya suatu perusahaan dalam mempertahankan eksistensi perusahaan dimulai dari usaha manusia itu sendiri dalam meningkatkan efektivitas dan efisiensi kerja secara maksimal.

Pencapaian ini juga perlu dikaitkan dengan perilaku dari karyawan selama proses pengembangan kinerja. Manajemen kinerja sering disebut sebagai bagian dari manajemen sumber daya manusia yang mempunyai efek terbesar terhadap kinerja organisasi. Lebih lanjut dinyatakan bahwa tujuan manajemen kinerja adalah menghubungkan atau mengkaitkan target serta tanggung jawab individu dengan target serta tanggung jawab dari unit kerja dan organisasi secara keseluruhan. Manajemen kinerja mengintegrasikan unsurunsur penting dalam manajemen sumber daya manusia seperti penilaian kinerja, pelatihan, 
pengembangan karir dan sistem penggajian. Oleh karena itu dapat dikatakan bahwa manajemen kinerja merupakan jantung dari manajemen sumber daya manusia.

Manajemen kinerja sangat penting dalam rangka menciptakan karyawan yang produktif dengan menyebut secara jelas output serta peran atau fungsi yang diharapkan dari seorang karyawan. Jika persyaratan yang diperlukan untuk setiap jabatan dan fungsi atau peran dari jabatan tersebut tidak diuraikan secara jelas, hal ini akan mengakibatkan duplikasi pekerjaan atau menumpuknya tanggung jawab pada sebagian karyawan yang dapat mempengaruhi kinerja dari suatu unit kerja di perusahaan tersebut.

Manajemen kinerja dapat menyebabkan pegawai lebih berinisiatif dan jika target dari setiap pegawai mengalami peningkatan dari waktu ke waktu pada akhirnya kinerja dan produktivitas pegawai juga akan meningkat secara kontinyu. Dalam banyak hal sistem kinerja memang mempunyai potensi yang besar untuk dapat mengembangkan kemampuan sumber daya manusia. Walaupun demikian dalam proses perencanaan dan implementasi sistem tersebut, ada beberapa hal yang perlu diperhatikan karena mempunyai potensi untuk menjadi kendala. Kendala tersebut dapat berasal dari perusahaan yang kadang kala mencakup hal-hal yang terlalu luas sehingga menjadi kurang atau bahkan tidak fokus. Hal tersebut ditambah lagi dengan proses komunikasi dari tujuan perusahaan yang kurang baik sehingga tidak setiap karyawan mengetahui dengan baik apa tujuan dari perusahaannya.

Biasanya kendala yang timbul dari manajemen kinerja adalah kesulitan yang timbul dalam penyusunan target bagi karyawan terutama pada awal implementasi sistem manajemen kinerja. Subyektifitas yang mungkin terjadi pada proses penilaian kinerja serta system lain terkait dengan penentuan gaji dan promosi.

Khusus mengenai subyektifitas perlu disadari bahwa sangatlah sulit dan bahkan mustahil untuk membuat suatu sistem yang diterapkan kepada manusia, dimana sistem tersebut benar-benar obyektif serta dapat memuaskan seluruh pihak. Hal ini disebabkan karena setiap karyawan mempunyai karakteristik yang berbeda-beda sehingga sulit dan/ mustahil untuk mengakomodasikan seluruh keinginan karyawan. Salah satu cara untuk menunjang organisasi agar mendapatkan keunggulan komparatif adalah dengan menghubungkan tujuan organisasi dengan sumber daya manusianya.

Tinggi atau rendahnya kinerja dapat diamati melalui jumlah jam kerja, tingkat pelayanan berupa kuantitas dan kualitas pelayanan yang dihasilkan. Sejauh ini kinerja karyawan di Toko Emas Semar Nganjuk sangat baik dan mampu melampaui target yang direncanakan.

Hal yang perlu dicermati adalah bahwa kinerja tersebut dapat tercapai karena tenaga kerja bekerja secara disiplin, yaitu mampu memenuhi standar kerja, norma-norma atau aturan yang telah direncanakan dan ditetapkan untuk mencapai tujuan yang telah ditetapkan. Sikap mental tersebut perlu ditanamkan dan dibentuk sejak dini, karena apabila disiplin kerja karyawan dapat ditingkatkan maka kinerja karyawan juga akan semakin meningkat.

Kedisiplinan merupakan kemampuan karyawan memenuhi standar kerja, normanorma atau aturan yang telah direncanakan untuk mencapai tujuan yang telah ditetapkan. Sikap mental tersebut perlu ditanamkan dan dibentuk sejak dini, karena apabila disiplin kerja karyawan dapat ditingkatkan maka produktivitas kerja akan semakin meningkat. Tinggi atau rendahnya produktivitas kerja di perusahaan dapat diamati melalui jumlah jam kerja, tingkat kerusakan produk, dan kuantitas serta kualitas produk yang dihasilkan.

Tantangan yang semakin meningkat dan dihadapi oleh perusahaan adalah upaya meningkatkan kedisiplinan karyawan. Hal ini berhubungan dengan penegakan peraturan dan tata tertib perusahaan. Ada sebagian 
karyawan yang tidak menginginkan perusahaan menetapkan peraturan dengan kaku. Karyawan menjadi takut dan berada dalam tekanan, dan hal ini justru mengurangi produktivitas kerja.

Moeheriono, dalam Pengukuran Kinerja Berbasis Kompetensi (2009:60) berpendapat bahwa kinerja atau performance merupakan gambaran mengenai tingkat pencapaian pelaksanaan suatu program kegiatan atau kebijakan dalam mewujudkan sasaran, tujuan, visi, dan misi organisasi yang dituangkan melalaui perencanaan strategis suatu organisasi.

Kinerja dapat diketahui dan diukur jika individu atau sekelompok karyawan telah mempunyai kriteria atau standart keberhasilan tolok ukur yang ditetapkan oleh organisasi. Oleh karena itu, jika tanpa tujuan dan target yang ditetapkan dalam pengukuran, maka kinerja pada seseorang tidak mungkin dapat diketahui bila tidak ada tolok ukur keberhasilannya.

Moeheriono, dalam Pengukuran Kinerja Berbasis Kompetensi (2009:61) berpendapat bahwa kinerja atau performance berasal dari kata-kata job performance dan disebut juga actual performance atau prestasi kerja serta prestasi sesungguhnya yang telah dicapai oleh seorang karyawan.

Mohamad Mahsun, dalam Pengukuran Kinerja Sektor Publik (2006: 25) berpendapat bahwa Kinerja (performance) adalah gambaran mengenai tingkat pencapaian pelaksanaan suatu kegiatan/program/ kebijakan dalam mewujudkan sasaran, tujuan, misi dan visi organisasi yang tertuang dalam strategic planning suatu organisasi.

Wibowo, dalam Manajemen Kinerja (2007:7) berpendapat bahwa kinerja atau performance adalah sebagai hasil kerja atau prestasi kerja. Namun, sebenarnya kinerja mempunyai makna yang lebih luas, bukan hanya hasil kerja. Tetapi termasuk bagaimana proses pekerjaan berlangsung. Kinerja merupakan hasil pekerjaan yang mempunyai hubungan kuat dengan tujuan strategis organisasi, kepuasan konsumen, dan memberikan kontribusi pada ekonomi.

Irham Fahmi dalam Manajemen Kinerja (2011:2) berpendapat bahwa kinerja adalah hasil yang diperoleh oleh suatu organisasi. Sebenarnya karyawan bisa saja mengetahui seberapa besar kinerja mereka melalui sarana informal, seperti komentar atau penilaian yang baik atau buruk dari atasan, mitra kerja, bahkan bawahan, tetapi seharusnya penilaian kinerja juga harus diukur melalui penilaian formal dan terstruktur.

Dari berbagai pengertian yang telah disebutkan di atas, maka pengertian kinerja dapat disimpulkan sebagai hasil yang telah dicapai oleh seseorang atau sekelompok orang dalam suatu organisasi baik secara kuantitatif maupun kualitatif, sesuai dengan kewenangan dan tugas serta tanggung jawab masing-masing, dalam upaya mencapai tujuan organisasi bersangkutan secara legal, tidak melanggar hukum dan sesuai dengan moral maupun etika.

Sebagaimana yang dikemukakan oleh Mohamad Mahsun, dalam Pengukuran Kinerja Sektor Publik (2006:26). Dari berbagai pengertian di atas, dapat disimpulkan elemen pokok suatu pengukuran kinerja antara lain adalah sebagai berikut:

\section{Menetapkan Tujuan, Sasaran, dan Strategi Organisasi}

Tujuan adalah pernyataan secara umum tentang apa yang ingin dicapai organisasi. Sasaran merupakan tujuan organisasi yang sudah dinyatakan secara ekplisit dengan berdasarkan waktu yang jelas. Strategi adalah suatu cara atau teknik yang digunakan organisasi untuk mencapai tujuan dan sasaran. Tujuan, sasaran, dan strategi tersebut ditetapkan dengan berpedoman pada visi dan misi organisasi. Berdasarkan tujuan, sasaran, dan strategi tersebut selanjutnya dapat ditentukan indikator dan ukuran kinerja secara tepat. 


\section{Merumuskan Indikator dan Ukuran Kinerja}

Indikator kinerja mengacu pada penilaian kinerja secara tidak langsung yaitu halhal yang sifatnya hanya merupakan indikasiindikasi kinerja. Ukuran kinerja mengacu pada penilaian kinerja secara langsung. Indikator kinerja dan ukuran kinerja ini sangat dibutuhkan untuk mengukur tingkat ketercapaian tujuan, sasaran dan strategi.

\section{Mengukur Tingkat Ketercapaian Tujuan dan Sasaran-Sasaran Organisasi}

Jika sudah mempunyai indikator dan ukuran kinerja yang jelas, maka pengukuran kinerja bisa diimplementasikan. Mengukur tingkat ketercapaian tujuan, sasaran dan strategi adalah membandingkan hasil actual dengan indikator dan ukuran kinerja ini menghasilkan penyimpangan positif, penyimpangan negatif, dan penyimpangan nol. Penyimpangan positif berarti pelaksanaan kegiatan sudah berhasil mencapai serta melampaui indikator dan ukuran kinerja yang ditetapkan. Penyimpangan negative berarti pelaksanaan kegiatan belum berhasil mencapai indikator dan ukuran kinerja yang telah ditetapkan. Penyimpangan nol berarti pelaksanaan kegiatan sudah berhasil mencapai atau sama dengan indikator dan ukuran kinerja yang ditetapkan.

\section{Evaluasi Kinerja}

Evaluasi kinerja akan memberikan gambaran kepada penerima informasi mengenai nilai kinerja yang berhasil dicapai organisasi. Capaian kinerja dapat dinilai dengan skala pengukuran tertentu. Informasi pencapaian kinerja dapat dijadikan feedback dan reward and punishment, penilaian kemajuan organisasi dan dasar peningkatan kualitas pengambilan keputusan dan akuntabilitas.

Sebagaimana yang telah dikemukakan oleh Wibowo, dalam bukunya Manajemen Kinerja (2007:11) mengemukakan bahwa prinsip dasar manajemen kinerja adalah sebagaiberikut:

\section{Kejujuran}

Kejujuran merupakan ciri dalam komunikasi umpan balik yang jujur di antara manajer, pekerja, dan rekan kerja. Kejujuran termasuk dalam mengekspresikan pendapat, menyampaikan fakta, memberikan pertimbangan dan perasaaan. Kejujuran mempunyai beberapa segi dan tingkatan, dan mereka yang menggunakan proses penilaian untuk menggali kebenaran secara luas dan dalam akan memperoleh manfaat terbesar.

\section{Pelayanan}

Setiap aspek dalam proses kinerja harus memberikan pelayanan kepada setiap stakeholder, yaitu: pekerja, manajer, pemilik, dan pelanggan. Dalam proses manajemen kinerja, umpan balik dan pengukuran harus membantu pekerja dan perencanaan kinerja. Prinsip pelayanan merupakan tanda yang paling kuat untuk pengukuran dan perencanaan.

\section{Tanggung Jawab}

Tanggung jawab merupakan prinsip dasar di belakang pengembangan kinerja. Dengan memahami dan menerima tanggung jawab atas apa yang mereka kerjakan dan tidak kerjakan untuk mencapai tujuan mereka, pekerja belajar tentang apa yang perlu mereka perbaiki.

\section{Bermain}

Manajemen kinerja menggunakan prinsip bahwa bekerja dengan bermain. Dengan prinsip ini orang mendapatkan kepuasan dari apa yang mereka kerjakan. Apabila tidak menggunakan prinsip bermain, pekerjaan akan menjadi beban.

\section{Rasa Kasihan}

Rasa kasihan merupakan prinsip bahwa manajer memahami dan empati terhadap orang lain. Kebanyakan orang yang tidak menunjukkan rasa kasihan pada orang lain juga sedikit sekali merasa pada diri mereka sendiri. Rasa kasihan seorang manajer akan 
melupakan kesalahan di belakang mereka dan mulai dengan sesuatu yang baru.

\section{Perumusan Tujuan}

Manajemen kinerja dimulai dengan perumusan dan mengklarifikasinya terlebih dahulu tujuan yang akan dicapai organisasi. Sesuai dengan jenjang organisasi yang dimiliki, selanjutnya tujuan yang sudah dirumuskan tersebut dirinci lebih lanjut menjadi tujuan di tingkat yang lebih rendah. Hal tersebut penting dilakukan agar tujuan semua tingkatan manajemen yang lebih rendah memberikan kontribusi pada pencapaian tujuan struktur di atasnya secara berjenjang.

\section{Konsensus dan Kerja Sama}

Manajemen kinerja mengandalkan pada konsensus dan kerja sama antara atasan dan bawahan daripada menekankan pada control dan melakukan paksaan. Apabila bawahan melakukan pekerjaan karena terpaksa, sebenarnya mereka tidak memberikan dukungan pada atasan. Apabila pekerjaan dilakukan atas dasar kerja sama, pekerjaan akan menjadi lebih bertanggung jawab.

\section{Berkelanjutan}

Manajemen kinerja merupakan suatu proses yang sifatnya berlangsung secara terus menerus, berkelanjutan, bersifat evolusioner, di mana kinerja secara bertahap akan selalu diperbaiki sehingga akan menjadi lebih baik.

\section{Komunikasi Dua Arah}

Manajemen kinerja memerlukan gaya manajemen yang bersifat terbuka dan jujur serta mendorong terjadinya komunikasi dua arah antara atasan dan bawahan. Komunikasi dua arah menunjukkan adanya sikap keterbukaan dan saling pengertian antara dua pihak. Dengan komunikasi dua arah, bawahan akan lebih memahami apa yang diinginkan atasan atau sebaliknya atasan akan lebih memahami apa saja yang diinginkan bawahannya.

\section{Umpan Balik}

Pelaksanaan manajemen kinerja memerlukan umpan balik terus-menerus. Umpan balik memungkinkan pengalaman dan pengetahuan yang diperoleh dari pekerjaan oleh individu dipergunakan untuk memodifikasi tujuan organisasi.

Supratmi. 2013. Pengaruh Tingkat Kompetensi dan Pengalaman Kerja Terhadap Etos Kerja. Jurnal-Sosioekotekno.Org. 3-4. Pengalaman kerja adalah proses pembentukan pengetahuan atau keterampilan tentang metode suatu pekerjaan karena keterlibatannya dalam pelaksanaan tugas pekerjaan.

Pengalaman kerja juga diartikan sebagai ukuran tentang lama waktu atau masa kerja yang telah ditempuh seseorang dapat memahami tugas-tugas suatu pekerjaan dan telah melaksanakan dengan baik. Berpengalaman dan tidaknya karyawan dapat dipengaruhi oleh lama waktu/masa kerja, tingkat pengetahuan dan keterampilan yang dimiliki, penguasaan pada pekerjaan dan peralatan. Oleh karena itu seorang karyawan yang mempunyai pengalaman kerja adalah seseorang yang mempunyai kemampuan jasmani, memiliki pengetahuan, dan keterampilan untuk bekerja serta tidak akan membahayakan bagi dirinya dalam bekerja. Dari uraian di atas peneliti dapat menyimpulkan bahwa kinerja karyawan dapat dipengaruhi beberapa faktor salah satunya adalah pengalaman kerja setiap karyawan itu sendiri.

Dalam melakukan pekerjaan seorang karyawan dalam bekerja dituntut memiliki pengalaman kerja yang mumpuni di bidang pekerjaannya. Menurut Undang-Undang Republik Indonesia Nomor 20 Tahun 2008 Tentang Usaha Mikro, Kecil, dan Menengah (2008:9-10) pengalaman kerja seorang karyawan dapat ditempuh dengan cara kemitraan melalui 3 pola yaitu:

\section{Inti-plasma}

Kemitraan dengan pola inti-plasma sebagaimana yang dimaksud adalah usaha 
besar sebagai inti yang membina dan mengembangkan usaha mikro, kecil, dan menengah, sehingga dapat berkembang dengan lebih baik lagi dan mempunyai kualitas karyawan yang baik. Erat kaitannya dengan hal tersebut seorang karyawan dapat memperoleh pengalaman kerja dengan cara masuk di dalamnya. Sesuai dengan judul yang diangkat peneliti dalam penelitian ini karyawan Toko Emas Semar Nganjuk dapat masuk dalam perusahaan yang lebih besar guna memperoleh pengalaman kerja yang maksimal sesuai dengan bidang pekerjaannya untuk dapat meningkatkan kinerjanya pada Toko Emas Semar Nganjuk.

Contoh: Sebelum masuk dan bekerja di Toko Emas Semar Nganjuk, setiap karyawannya wajib menempuh pelatihan guna meningkatkan pengalaman kerja di bidang pekerjaan yang sesuai, misalnya dengan bekerja di toko emas yang lebih besar dari Toko Emas Semar Nganjuk, dengan demikian karyawan akan mempunyai pengalaman kerja yang matang dan akan lebih siap dalam menjalankan kinerja di Toko Emas Semar Nganjuk.

\section{Subkontrak}

Kemitraan dengan pola subkontrak ini adalah dimana perusahaan besar memberikan dukungan salah satunya dengan memberikan kesempatan untuk mengerjakan sebagian produksi dan/atau komponennya. Sesuai dengan penelitian ini seorang karyawan pada Toko Emas Semar Nganjuk dapat memperoleh pengalaman kerja dengan pola subkontrak ini dengan cara masuk di dalam perusahaan yang lebih besar dengan bidang pekerjaan yang sama guna mendapatkan pengalaman kerja yang lebih baik lagi. Dengan demikian karyawan pada Toko Emas Semar Nganjuk akan memperoleh pengalaman kerja di bidangnya yang lebih mumpuni untuk dapat mewujudkan tujuan dari perusahaan yang bersangkutan.

Contoh: Toko emas yang lebih besar dari Toko Emas Semar Nganjuk dapat memberikan kesempatan kepada karyawan Toko Emas
Semar Nganjuk untuk membantu kegiatan produksi guna memenuhi permintaan dari konsumen yang semakin meningkat dari toko emas yang lebih besar tersebut untuk dapat meningkatkan kinerja karyawan Toko Emas Semar Nganjuk.

\section{Waralaba}

Perusahaan besar yang memperluas usahanya dengan pola kemitraan waralaba ini akan dapat menyerap tenaga kerja atau karyawan untuk dapat mendukung usahanya, dalam hal ini adalah perusahaan yang berkaitan dengan penelitian yang dilakukan oleh peneliti. Berkaitan dengan penelitian ini seorang karyawan dapat menambah atau meningkatkan pengalaman kerjanya dengan cara masuk dalam pola kemitraan waralaba ini untuk meningkatkan kinerjanya. Pemberi waralaba wajib memberikan pembinaan dalam bentuk pelatihan, bimbingan operasional manajemen, pemasaran, penelitian, dan pengembangan kepada penerima waralaba secara berkesinambungan.

Contoh: Perusahaan yang lebih besar dari Toko Emas Semar Nganjuk yang mengembangkan usahanya otomatis membutuhkan karyawan guna menunjang usahanya, dengan melalui pola waralaba ini perusahaan ini dapat meminta sebagian karyawan Toko Emas Semar Nganjuk terutama karyawan dengan pengalaman kerja yang kurang. Melalui waralaba karyawan tersebut secara otomatis mendapatkan pembinaan, pelatihan, serta bimbingan dari perusahaan yang memberikan waralaba. Dengan demikian para karyawan akan bertambah pengalaman menjadi lebih baik dan produktif dalam kegiatan produksi perusahaan yang bersangkutan, khususnya Toko Emas Semar Nganjuk guna meningkatkan kinerjanya.

Dari uraian di atas dapat diketahui bahwa pengalaman kerja seorang karyawan salah satunya dapat dipengaruhi oleh ketiga pola kemitraan sesuai dengan UndangUndang Republik Indonesia Nomor 20 Tahun 2008 yaitu pola kemitraan inti-plasma, 
subkontrak, dan waralaba. Pengalaman kerja tidak hanya dapat dipengaruhi dari diri setiap karyawan itu sendiri, melainkan terdapat banyak faktor yang dapat mempengaruhi pengalaman kerja setiap karyawan seperti yang diuraikan di atas.

Setiap karyawan selalu dituntut berpengalaman dalam melakukan pekerjaan, itulah sebabnya seorang karyawan dapat menempuh segala media pelatihan kerja guna meningkatkan kinerjanya, sehingga dengan demikian mereka akan secara otomatis menjadi incaran setiap perusahaan kecil ataupun besar guna direkrut menjadi karyawan yang dapat menunjang kegiatan produksi perusahaan yang bersangkutan.

\section{METODE}

Penelitian ini mengambil tempat di Toko Emas Semar Nganjuk. Yang beralamat pada Jl. Raya Nganjuk Kediri Kab. Nganjuk. Pemilihan lokasi dilakukan secara sengaja/ purposif dengan mempertimbangkan lokasi tersebut sebagai daerah pemukiman yang menjadi pusat mobilisasi penduduk sekitar, sehingga memudahkan peneliti dalam mengambil data.

Penelitian yang digunakan untuk mengetahui Pengaruh Pengalaman Kerja Terhadap Kinerja Karyawan Pada Toko Emas Semar Nganjuk ini menggunakan angket untuk mendapatkan data yang diinginkan oleh peneliti. Penelitian ini adalah untuk memperoleh suatu informasi secara mendalam tetapi tidak meluas, dan pada akhirnya untuk memperoleh pengetahuan ilmiah yang bersifat spesifik, konkrit dan fokus.

Sebagaimana yang telah dikemukakan oleh Suharsimi Arikunto dalam buku Prosedur Penelitian (1997:129) adapun keuntungan dan kelemahan kuisioner adalah sebagai berikut:

\section{Keuntungan Kuisioner}

a. Tidak memerlukan hadirnya peneliti.

b. Dapat dibagikan secara serentak kepada banyak responden.

c. Dapat dijawab oleh responden menurut kecepatannya masing-masing dan menurut waktu senggang responden.

d. Dapat dibuat anonim sehingga responden bebas jujur dan tidak malu-malu menjawab.

e. Dapat dibuat terstandar sehingga bagi semua responden dapat diberi pertanyaan yang benar-benar sama.

\section{Kelemahan Kuisioner}

a. Responden sering tidak teliti dalam menjawab sehingga ada pertanyaan yang terlewati tidak dijawab, padahal sukar diulangi diberikan kembali kepadanya.

b. Seringkali sukar dicari validitasnya.

c. Walaupun dibuat anonim, kadang-kadang responden dengan sengaja memberikan jawaban yang tidak betul atau tidak jujur.

d. Seringkali tidak kembali, terutama jika dikirim lewat pos.

e. Waktu pengembaliannya tidak bersamasama, bahkan kadang-kadang ada yang terlalu lama sehingga terlambat.

Dengan mempergunakan angket peneliti mencari validitas angket atau kuisioner dan reliabilitas angket terlebih dahulu untuk menentukan angket tersebut layak atau tidak dipergunakan dalam penelitian ini untuk mendapatkan data yang diperlukan peneliti dalam penelitian.

Validitas dan reliabilitas angket dapat dicari dengan rumus sebagai berikut:

$$
\begin{aligned}
& r_{x y}=\frac{(N \Sigma \Sigma X Y)-\left(\sum X\right)\left(\sum Y\right)}{\sqrt{\left(\left(N \cdot \Sigma X^{2}\right)-(\Sigma X)^{2}\right)\left(\left(N \cdot \Sigma \gamma^{2}\right)-\left(\sum \eta^{2}\right)\right.}} \\
& =\frac{(40 \times 1562)-(252)(242)}{\sqrt{\left\{(40 \times 1684)-(252)^{2}\right\}\left\{(40 \times 1601)-(242)^{2}\right\}}} \\
& =\frac{62480-60894}{\sqrt{\{(67360)-(63504)\}\{(64040)-(58564)\}}} \\
& =\frac{1586}{\sqrt{(3856)(5474)}} \\
& =\frac{1586}{\sqrt{21107744}} \\
& =\frac{1586}{4594,32} \\
& =0,345
\end{aligned}
$$


Berdasarkan hasil perhitungan di atas dapat diketahui besarnya korelasi (r) adalah 0,345 yang merupakan korelasi positif, yaitu jika Pengalaman Kerja (X) meningkat maka secara proporsional Kinerja Karyawan (Y) juga meningkat. Demikian pula sebaliknya, apabila Pengalaman Kerja (X) menurun maka secara proposional Kinerja Karyawan (Y) juga akan menurun. Hal ini memberikan penjelasan bahwa untuk dapat meningkatkan Kinerja Karyawan pada Toko Emas Semar Nganjuk harus berupaya meningkatkan Pengalaman Kerja Setiap Karyawannya.

Setelah melakukan perhitungan validitas angket atau kuisioner dan mendapatkan hasil koefisien korelasi (r) sebesar 0,345 . Langkah selanjutnya yang dilakukan peneliti adalah mencari Reliabilitas dengan rumus sebagai berikut:

$$
V=\frac{\sum X^{2}-\frac{\left(\sum X\right)^{2}}{N}}{N}
$$

(Suharsimi Arikunto, 1997:160)

$$
\begin{aligned}
V & =\frac{\sum X^{2}-\frac{\sum X^{2}}{N}}{N} \\
& =\frac{1684-\frac{65504}{40}}{40} \\
& =\frac{1684-1587,6}{40} \\
& =\frac{96,4}{40} \\
& =2,41
\end{aligned}
$$

Penelitian ini menggunakan metode deskriptif dimana dalam penelitian ini menggunakan dua variabel, yaitu variabel bebas dan variabel terikat. Dimana dijelaskan bahwa pengalaman kerja merupakan variabel bebas (X), dan kinerja karyawan toko Emas Semar Nganjuk sebagai variabel terikatnya (Y). Sesuai uraian di atas dapat diketahui bahwa kedua variabel yaitu bebas dan variabel terikat dalam penelitian ini adalah saling mempengaruhi satu sama lain, dimana pengalaman kerja karyawan Toko Emas Semar Nganjuk dapat berpengaruh terhadap kinerja karyawan tersebut dan kinerja karyawan dapat dipengaruhi oleh pengalaman kerja. Hal tersebut dapat digambarkan sebagai berikut:

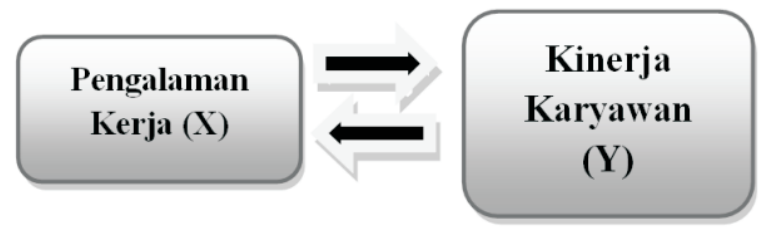

\section{Populasi dan Sampel Penelitian}

Suharsimi Arikunto dalam buku Prosedur Penelitian (1997:108) menyatakan populasi adalah keseluruhan subyek penelitian. Dengan demikian populasi dari penelitian ini adalah seluruh Karyawan Pada Toko Emas Semar Nganjuk.

Penelitian ini menggunakan teknik pengambilan sampel model sampling jenuh. Sugiyono dalam buku metode penelitian pendidikan (2010:124-125) berpendapat bahwa sampling jenuh adalah teknik penentuan sampel bila semua anggota populasi digunakan sebagai sampel.

Hal ini sering dilakukan bila jumlah populasi relatif kecil, kurang dari 30 orang, atau penelitian yang ingin membuat generalisasi dengan kesalahan yang sangat kecil. Istilah lain sampel jenuh adalah sensus, dimana semua anggota populasi dijadikan sampel.

Dalam penelitian ini hanya terdapat subyek penelitian sebanyak 40 orang, maka peneliti mengambil semua subyek penelitian untuk dijadikan sampel penelitian.

\section{Variabel Penelitian}

Dalam penelitian ini menggunakan dua variabel, yaitu variabel bebas dan variabel terikat. Dimana dijelaskan bahwa pengalaman kerja merupakan variabel bebas $(\mathrm{X})$, dan kinerja karyawan toko Emas Semar Nganjuk sebagai variabel terikatnya(Y). 


\section{HASIL}

Berdasarkan 40 kuisioner yang disebar kepada 40 responden pada Toko Emas Semar Nganjuk diperoleh nilai rata-rata, nilai minimum dan maksimum serta standar deviasi variabel penelitian pada pengalaman kerja dan kinerja karyawan Toko Emas Semar Nganjuk adalah sebagai berikut:

\begin{tabular}{|c|c|c|c|c|c|c|}
\hline \multicolumn{7}{|c|}{ Deskriptif Statistik Pengalaman Kerja } \\
\hline & $\mathrm{N}$ & $\begin{array}{l}\text { Mini } \\
\text { mum }\end{array}$ & $\begin{array}{l}\text { Maxi } \\
\text { mum }\end{array}$ & \multicolumn{2}{|c|}{ Mean } & $\begin{array}{c}\text { Std. } \\
\text { Deviation }\end{array}$ \\
\hline & $\begin{array}{l}\text { Statis } \\
\text { tik }\end{array}$ & $\begin{array}{c}\text { Statis } \\
\text { tik }\end{array}$ & $\begin{array}{c}\text { Statis } \\
\text { tik }\end{array}$ & $\begin{array}{c}\text { Statis } \\
\text { tik }\end{array}$ & $\begin{array}{l}\text { Std. } \\
\text { Error }\end{array}$ & Statistik \\
\hline $\begin{array}{l}\text { Pengala- } \\
\text { man }\end{array}$ & 40 & 3.00 & 9.00 & 6.3000 & .24859 & 1.57219 \\
\hline $\begin{array}{l}\text { Valid N } \\
\text { (listwise) }\end{array}$ & 40 & & & & & \\
\hline
\end{tabular}

Pengalaman kerja karyawan Toko Emas Semar Nganjuk mempunyai nilai minimum 3, nilai maksimum 9, dengan ratarata jawaban responden adalah sebesar 6.3000 dengan standar deviasi 1.57219 .

Hal di atas mempunyai makna bahwa dari 40 orang responden karyawan pada Toko Emas Semar Nganjuk yang memiliki pengalaman kerja di atas rata-rata statistik $\geq$ 6.3000 adalah sebanyak 26 orang atau sebesar $65 \%$ dari 40 orang responden Toko Emas Semar Nganjuk sedangkan yang memiliki pengalaman kerja di bawah rata-rata adalah 14 orang, hal ini dapat disimpulkan bahwa pengalaman kerja karyawan pada Toko Emas Semar Nganjuk adalah baik.

\section{Deskriptif Statistik Kinerja Karyawan}

\begin{tabular}{|c|c|c|c|c|c|c|}
\hline & $\mathrm{N}$ & $\begin{array}{l}\text { Mini } \\
\text { mum }\end{array}$ & $\begin{array}{l}\text { Maxi } \\
\text { mum }\end{array}$ & \multicolumn{2}{|c|}{ Mean } & $\begin{array}{c}\text { Std. } \\
\text { Deviation }\end{array}$ \\
\hline & $\begin{array}{c}\text { Statis } \\
\text { tik }\end{array}$ & $\begin{array}{c}\text { Statis } \\
\text { tik }\end{array}$ & $\begin{array}{c}\text { Statis } \\
\text { tik }\end{array}$ & $\begin{array}{c}\text { Statis } \\
\text { tik }\end{array}$ & $\begin{array}{l}\text { Std. } \\
\text { Error }\end{array}$ & Statistik \\
\hline Kinerja & 40 & 3.00 & 9.00 & 6.0500 & .25306 & 1.60048 \\
\hline $\begin{array}{l}\text { Valid N } \\
\text { (listwise) }\end{array}$ & 40 & & & & & \\
\hline
\end{tabular}

Berdasarkan tabel di atas dapat diketahui bahwa kinerja karyawan Toko Emas Semar Nganjuk mempunyai nilai minimum sebesar 3, nilai maksimum 9 dengan rata-rata jawaban responden adalah sebesar 6.0500 dengan standar deviasi 1.60048 .
Dari uraian di atas mempunyai makna bahwa dari 40 orang responden karyawan pada Toko Emas Semar Nganjuk yang memiliki kinerja di atas rata-rata statistik $\geq$ 6.0500 adalah sebanyak 24 orang atau $60 \%$ dari 40 orang responden Toko Emas Semar Nganjuk sedangkan karyawan dengan kinerja di bawah rata-rata adalah 16 orang, hal ini dapat disimpulkan bahwa kinerja karyawan pada Toko Emas Semar Nganjuk adalah baik.

\section{Diagram Pencar Regresi Linier Sederhana variabel $X$ dan $Y$}

\section{Diagram Pencar}

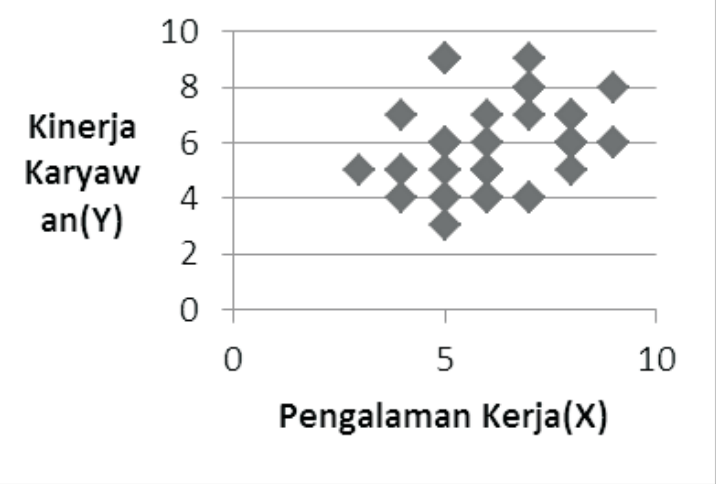

$Y^{\prime}=a+b X$

(Budiyono 2004:254)

$a=\frac{\left(\sum Y\right)\left(\sum X^{2}\right)-\left(\sum X\right)(\Sigma X Y)}{N \Sigma X^{2}-(\Sigma X)^{2}}$

(Budiyono 2004:254)

$b=\frac{N(\Sigma X Y)-(\Sigma X)(\Sigma X Y)}{N \Sigma X^{2}-(\Sigma X)^{2}}$

(Budiyono 2004:254)

Dari tabel diperoleh nilai $a$ dan $b$ sebagai berikut:

$$
\begin{aligned}
& =\frac{\left(\sum Y\right)\left(\sum X^{2}\right)-\left(\sum X\right)\left(\sum X Y\right)}{N \sum X^{2}-\left(\sum X\right)^{2}} \\
& a= \\
& \frac{242)(1684)-(2520)(1562)}{40(1684)-63504} \\
& \quad=\frac{407528-393624}{67360-63504} \\
& \quad=\frac{13904}{3856} \\
& \quad=3,606
\end{aligned}
$$




$$
\begin{aligned}
b & =\frac{N\left(\sum X Y\right)-\left(\sum X\right)\left(\sum X Y\right)}{N \sum X^{2}-\left(\sum X\right)^{2}} \\
b & =\frac{40(1562)-(252)(242)}{40(1684)-63504} \\
& =\frac{62480-60984}{67360-63504} \\
& =\frac{1496}{3856} \\
& =0,388
\end{aligned}
$$

Sehingga persamaan regresi yang memperlihatkan tidak adanya hubungan kedua variabel antara pengalaman kerja dan kinerja

\begin{tabular}{|c|c|c|c|c|c|}
\hline Model & $\begin{array}{l}\text { Sum of } \\
\text { Squares }\end{array}$ & Df & $\begin{array}{l}\text { Mean } \\
\text { Square }\end{array}$ & $\mathrm{F}$ & Sig. \\
\hline 1 Regression & 4.751 & 1 & 4.751 & 1.897 & $.176^{\mathrm{a}}$ \\
\hline Residual & 95.149 & 38 & 2.504 & & \\
\hline Total & 99.900 & 39 & & & \\
\hline
\end{tabular}
karyawan pada Toko Emas Semar Nganjuk adalah $Y=\mathbf{3 , 6 0 6}+\mathbf{0 , 3 8 8}$.

\section{Uji Fisher}

ANOVA $^{b}$

a. Predictors: (Constant), PENGALAMAN KERJA

b. Dependent Variable:

KINERJA KARYAWAN

Dari data SPSS di atas maka dapat diketahui besarnya $F_{\text {hitung }}$ adalah 1,897. Langkah selanjutnya adalah menentukan $F_{\text {tabel }}$ dengan rumus sebagai berikut:

$$
\begin{aligned}
& F_{\text {hitung }=1,897} \\
& \begin{array}{l}
\alpha=5 \%=0,05 \\
d k=N-1 \\
\quad=40-1 \\
\quad=39
\end{array} \\
& \begin{array}{l}
F_{\text {tabel }}=F_{0.05} ; 39 \\
F_{\text {hitung }}<F_{\text {tabel }}=
\end{array}=2,023 \\
& \text { Terima } H_{0}
\end{aligned}
$$

Setelah mengetahui persamaan rumus regresi linier sederhana selanjutnya adalah melakukan uji F, ini dilakukan dengan menggunakan SPSS dengan memperoleh hasil $F_{\text {hitung }}<F_{\text {tabel }}=$ Terima $H_{0}$. Ini mem- buktikan bahwa tidak ada pengaruh pengalaman kerja dengan kinerja karyawan pada Toko Emas Semar Nganjuk.

\section{PEMBAHASAN}

\section{Pembahasan Uji Korelasi}

Dari hasil perhitungan dalam pengujian hipotesis di atas telah diperoleh angka koefisien korelasi (r) sebesar 0,345. Hal ini merupakan korelasi yang positif tetapi pengaruh kedua variabel, yaitu Pengalaman Kerja (X) terhadap Kinerja Karyawan termasuk kategori hubungan yang rendah.

Berdasarkan kriteria atau interpretasi yang dikemukakan Suharsimi pada sub bab sebelumnya, jelaslah bahwa koefisien korelasi (r) sebesar 0,345 termasuk kategori hubungan yang rendah. Hal ini mengandung pengertian bahwa sebenarnya kinerja karyawan tidak hanya tergantung atau terpengaruh oleh pengalaman kerja karyawan, melainkan ada faktor-faktor lain yang ikut berpengaruh terhadap kinerja karyawan.

\section{Pembahasan Uji Fisher}

Uji Fisher membuktikan bahwa $F_{\text {hitung }}<$ $F_{\text {tabel }}=$ yaitu $1.897<2,023$ yang berarti bahwa terima $H_{0}$ yang menyatakan bahwa tidak adanya pengaruh antara pengalaman kerja terhadap kinerja karyawan pada Toko Emas Semar Nganjuk.

Sehubungan dari hasil penelitian yang telah dilakukan peneliti mendapatkan hasil tidak ada pengaruh antara pengalaman kerja terhadap kinerja karyawan pada Toko Emas Semar Nganjuk, meskipun secara teori pengalaman kerja setiap karyawan akan dapat mempengaruhi kinerjanya dalam bekerja, maka peneliti melakukan wawancara dengan Bapak Hery Marwanto selaku pemimpin Toko Emas Semar Nganjuk pada hari Rabu tanggal 24 Juli 2013 pukul 08.00 - 09.00 wib untuk mengetahui faktor apa saja yang dapat mempengaruhi kinerja karyawan pada Toko Emas Semar Nganjuk. 
Mengingat hasil penelitian merupakan faktor yang paling pokok dan terpenting dalam sebuah penelitian, oleh karena itu peneliti melakukan wawancara kepada pemimpin Toko Emas Semar Nganjuk secara langsung untuk mengetahui faktor apa saja yang mempengaruhi kinerja karyawannya. Dengan demikian, akan dapat diketahui faktor-faktor apa saja yang paling berpengaruh terhadap Kinerja Karyawan pada Toko Emas Semar Nganjuk.

Dari hasil wawancara yang telah dilakukan peneliti maka didapatkan hasil sebagai berikut:

1. Kinerja setiap karyawan dapat dipengaruhi oleh faktor usia, dimana karyawan dengan usia produktif akan lebih mahir dalam kinerjanya.

2. Pendidikan setiap karyawan dapat mempengaruhi kinerja setiap karyawan, semakin tinggi tingkat pendidikan karyawan maka kinerja karyawan tersebut juga semakin baik.

3. Tingkat kesehatan setiap karyawan juga sangat mempengaruhi hasil kinerjanya.

Dari hasil wawancara peneliti dengan pemimpin Toko Emas Semar Nganjuk di atas maka peneliti mengetahui faktor apa saja yang dapat mempengaruhi kinerja karyawan pada Toko Emas Semar Nganjuk selain pengalaman kerja pada setiap karyawannya.

Secara teori pengalaman kerja dapat mempengaruhi kinerja seorang karyawan namun hal tersebut belum dinyatakan benar sebelum adanya penelitian yang mendalam. Dari penelitian inilah dapat diketahui pengalaman kerja belum tentu dapat mempengaruhi kinerja seorang karyawan, namun adanya faktor-faktor lain yang dapat mempengaruhi kinerja seorang karyawan seperti yang diuraikan di atas.

\section{KESIMPULAN DAN SARAN}

\section{Simpulan Deskriptif Pengalaman Kerja}

Berdasarkan data dari tabel analisis deskriptif dapat dilihat bahwa pengalaman kerja karyawan Toko Emas Semar Nganjuk mempunyai nilai minimal 3, nilai maksimal 9, dengan rata-rata jawaban responden adalah sebesar 6.3000 dengan standar deviasi 1.57219. Hal ini mempunyai makna bahwa dari 40 orang responden karyawan pada Toko Emas Semar Nganjuk yang memiliki pengalaman kerja di atas rata-rata statistik $\geq 6.3000$ adalah sebanyak 26 orang atau sebesar $65 \%$ dari 40 orang responden Toko Emas Semar Nganjuk sedangkan yang memiliki pengalaman kerja di bawah rata-rata adalah 14 orang, hal ini dapat disimpulkan bahwa pengalaman kerja karyawan pada Toko Emas Semar Nganjuk adalah baik.

\section{Simpulan Deskriptif Kinerja Karyawan}

Dari data tabel analisis deskriptif Kinerja karyawan Toko Emas Semar Nganjuk mempunyai nilai minimum sebesar 3 , nilai maksimum 9 dengan rata-rata jawaban responden adalah sebesar 6.0500 dengan standar deviasi 1.60048 mempunyai makna bahwa dari 40 orang responden karyawan pada Toko Emas Semar Nganjuk yang memiliki kinerja di atas rata-rata statistik $\geq$ 6.0500 adalah sebanyak 24 orang atau $60 \%$ dari 40 orang responden Toko Emas Semar Nganjuk sedangkan karyawan dengan kinerja di bawah rata-rata adalah 16 orang, hal ini dapat disimpulkan bahwa kinerja karyawan pada Toko Emas Semar Nganjuk adalah baik.

Dari hasil uraian di atas kinerja karyawan Toko Emas Semar Nganjuk dapat dipengaruhi faktor lain yaitu tingkat pendidikan, usia, dan kesehatan namun tidak diteliti dalam penelitian ini melainkan dengan cara melakukan wawancara dengan pemimpin Toko Emas Semar Nganjuk secara langsung untuk mendapatkan jawaban yang diperlukan dalam penelitian ini.

Adapun langkah-langkah yang dapat dilakukan Toko Emas Semar Nganjuk untuk meningkatkan kinerja setiap karyawannya dapat dilakukan dengan cara berikut:

a. Meningkatkan dan menambah pengalaman kerja setiap karyawannya. 
b. Rekrutmen calon karyawan dengan pengalaman kerja yang cukup baik.

\section{Saran}

Pada dasarnya penelitian ini terbatas yang mencari dan menemukan Pengaruh 2 (dua) variabel, yaitu Pengalaman Kerja dan Kinerja Karyawan pada Toko Emas Semar Nganjuk melalui alat analisis dengan menggunakan regresi linier sederhana. Oleh karena itu penulis menyadari bahwa penarikan simpulan dalam penelitian ini masih kurang akurat hal ini disebabkan karena hanya menemukan pengaruh dua variabel penelitian saja.

Peneliti menyarankan kepada para peneliti yang akan datang untung dapat mempergunakan alat peneliti yang lebih lengkap dan spesifik guna dapat menyempurnakan hasil penelitian yang lebih lengkap dan tepat sasaran.

\section{Bagi Toko Emas Semar Nganjuk}

Diharapkan dapat mengetahui kekurangan yang ada pada Toko Emas Semar Nganjuk dan diharapkan mampu mengatasi permasalahan yang terjadi. Mengingat hasil penelitian yang menunjukkan bahwa pengalaman kerja setiap karyawan pada Toko Emas Semar Nganjuk tidak terbukti berpengaruh secara total terhadap kinerja karyawannya, melainkan adanya faktor-faktor lain yang dapat mempengaruhi kinerja karyawan pada Toko Emas Semar Nganjuk yaitu antara lain faktor usia, faktor pendidikan, dan faktor kesehatan setiap karyawan yang bekerja di Toko Emas Semar Nganjuk.

Diharapkan pemimpin toko mampu mengatasi permasalahan tersebut dengan cara memberikan pelatihan secara khusus dengan berbagai cara guna meningkatkan pengalaman kerja setiap karyawannya dan diharapkan mampu meningkatkan kinerja karyawan Toko Emas Semar Nganjuk.

\section{Bagi Peneliti Mendatang}

Diharapkan untuk memperoleh hasil yang lebih akurat, penulis menyarankan kepada peneliti yang akan datang untuk menggunakan alat analisis yang lebih spesifik. Hal tersebut dikarenakan hasil penelitian ini menunjukkan bahwa tidak adanya pengaruh antara dua variabel yaitu pengalaman kerja (X) dan kinerja karyawan (Y). mengingat hasil penelitian merupakan faktor penting dalam sebuah penelitian penulis menyarankan kepada peneliti yang akan datang untuk dapat menyempurnakan penelitian ini agar menjadi lebih baik dan lebih akurat.

\section{DAFTAR PUSTAKA}

Budiyono. 2004. Statistika untuk Penelitian. Surakarta: Universitas Sebelas Maret.

Irham Fahmi. 2011. Manajemen Kinerja. Bandung: ALVABETA, cv.

Mohamad Mahsun, S.E., M.Si, Ak. 2006. Pengukuran Kerja Sektor Publik. Yogyakarta: BPFE-Yogyakarta.

Prof. Dr. Moeheriono, M.Si. 2010. Pengukuran Kinerja Berbasis Kompetensi. Bogor: Ghalia Indonesia.

Prof. Dr. Sugiyono. 2010. Metode Penelitian Pendidikan. Bandung: ALVABETA, cv.

Prof. Dr. Suharsimi Arikunto. 1997. Prosedur Penelitian. Jakarta: PT. Rineka Cipta.

Supratmi. 2013. Pengaruh Tingkat Kompetensi dan Pengalaman Kerja Terhadap Etos Kerja. JurnalSosioekotekno.org.3-4.

Prof. Dr. Wibowo, S.E., M.Phil. 2007. Manajemen Kinerja. Jakarta: PT. Raja Grafindo Persada.

Undang-Undang Republik Indonesia Nomor 20 Tahun 2008. 